УДК 342.9(477)

DOI https://doi.org/10.32837/pyuv.v0i1(30).522

\author{
М. В. Корнієнко \\ orcid.org/0000-0002-6420-6169 \\ доктор юридичних наук, доцент, \\ завідувач кафедри адміністративної діяльності поліиіі \\ Одеського державного університету внутрішніх справ
}

\title{
ДЕЯКІ АСПЕКТИ ВИКОРИСТАННЯ МІЖНАРОДНОГО ДОСВІДУ ПІД ЧАС РОЗСЛІДУВАННЯ НАСИЛЬНИЦЬКИХ ЗЛОЧИНІВ ЩОДО ДІТЕЙ
}

Постановка проблеми. Нині в Україні відбуваються складні соціально-економічні перетворення, які впливають на збільшення випадків потрапляння дитини у складні життєві обставини, вчинення жорстокого поводження щодо дитини, втягування дітей у кримінальні угруповання, залучення до жебрацтва та скоєння відносно дітей насильницьких злочинів, як ніколи діти потребують захисту та допомоги держави.

Сучасне правове дослідження в умовах глобалізації та євроінтеграції не може не враховувати порівняльно-правовий аспект. Становлення i розвиток юридичної компаративістики є важливим фактором удосконалення правозастосовної діяльності органів державної влади, в тому числі і у сфері діяльності правоохоронних органів, зокрема протидії насильницьким злочинам проти дітей. «Злочини проти малолітніх останнім часом починають набувати міжнародного характеру. Винні особи можуть переїжджати з держави в державу, зокрема у країни, які розвиваються, зважаючи на меншу суворість покарання» [1], - наголошує Інтерпол. Слід зазначити, що запозичення досвіду розвинутих країн, насамперед держав Європи, має певні проблемні аспекти, пов'язані з різним законодавчим регулюванням відповідних суспільних відносин.

Аналіз останніх досліджень і публікацій. Розглядом окремих аспектів використання міжнародного досвіду при розслідуванні насильницьких злочинів щодо дітей займалися науковці Є.О. Безсмертний, Ю.П. Битяк, А.Б. Блага, О.В. Бойко, А.С. Васильєва, Т.І. Возна, І.П. Голосніченко, Г.В. Джагупов, Ф.К. Думко, Т.Г. Зайцева, Г.Є. Запорожцев, А.М. Кучук, В.К. Колпаков, А.Т. Комзюк, О.В. Негодченко, І.О. Панов та інші.

Формування цілей. Натепер в Україні реалізуються підходи, визначені міжнародним і вітчизняним законодавством щодо захисту прав дітей. Держава захищає інтереси дитини, удосконалює механізм контролю за дотриманням чинного законодавства у сфері охорони дитинства, розвиває та вдосконалює інституції соціально-правового захисту дітей, але цього замало, існує безліч прогалин у законодавстві, які потребують вирішення найближчим часом.
Завдання. Для більш ефективного розслідування насильницьких злочинів щодо дітей і запозичення позитивного міжнародного досвіду необхідно узагальнити деякі сучасні тенденції і стратегії протидії насильницькій злочинності щодо малолітніх, розглянути типові проблеми у запобіганні злочинності, з якими стикаються в різних державах.

Виклад основного матеріалу. «Для України за нинішніх умов особливої уваги науковців і практиків у цьому контексті потребує зарубіжний досвід як країн з міцним громадянським суспільством і правовою державою, так і країн, в яких демократичні інститути лише формуються. Держава за допомогою правових норм і застосування владних важелів регулює суспільні відносини, встановлює і підтримує в країні необхідний порядок, проте й сама підпорядковується суспільству, покликана служити йому» [2, с. 211], - зазначає А. Дакал.

Особливості розслідування насильницьких злочинів щодо дітей мають свою специфіку, пов'язану із психосоматичними особливостями дитини. Загалом практика розслідування таких злочинів у державах Європи та Сполучених Штатах Америки здійснюється в межах кримінального провадження, враховує психосоматичні особливості дитини. Надзвичайно важливим аспектом, який враховують передові держави в таких справах, є забезпечення інтересів дитини та її психологічного здоров'я. Водночас розслідування насильницьких злочинів щодо дітей в державах Свропи та Сполучених Штатах Америки (як і в нашій державі) має і певні труднощі, пов'язані з необхідністю удосконалення нормативно-правової бази, прискорення процесу розслідування тощо.

Світова спільнота приділяє все більше уваги залученню громадськості в різних їі виявах до справи протидії насильницькій злочинності, особливостям при вчиненні такої злочинності щодо дітей. Прогресивна міжнародна практика громадського впливу на злочинність та активізація іiї діяльності в цій сфері свідчить, що найчастіше громадськість використовується з метою вивчення стану місцевої злочинності (Колумбія, ПАР); запобігання рецидивній злочинності (Сінгапур, Бразилія, Уганда, Кенія); охорони громадського 
порядку (США, Велика Британія, Перу, Бразилія); фінансового заохочення громадськості за їі внесок у справу запобігання злочинності (Австралія, Канада); використання засобів комунікації в запобіганні злочинності (США, Велика Британія, Австралія) тощо.

Типовими проблемами щодо забезпечення широкої участі громадськості в запобіганні злочинності, з якими стикаються в різних державах, $\epsilon$ обмеженість знань про порядок і умови застосування стратегії громадського впливу на насильницьку злочинність щодо малолітніх дітей; відсутність традиційних доброзичливих стосунків між поліцією та місцевим населенням; недостатність політичної волі на розширення суб'єктів запобігання злочинності; слабкий розвиток підрозділів охорони громадського порядку; обмеження використання працівників служб пробації щодо нагляду за поведінкою осіб, звільнених від відбування покарання з випробуванням тощо.

Розслідування насильницьких злочинів щодо малолітніх відрізняється від розслідування насильницьких злочинів щодо повнолітніх осіб і частково неповнолітніх. Саме тому в європейських державах, зокрема Великій Британії, а також Сполучених Штатах Америки, кожне кримінальне провадження в справах щодо малолітніх здійснюється особами, які отримали спеціальні навички, пройшли відповідне навчання.

Найбільша різниця в розслідуванні насильницьких злочинів щодо дітей та дорослих пов'язана зі слуханням дітей як скаржників. Дитина у віці до 15 років не буде допитуватися в суді, тому іï свідчення на етапі попереднього слідства становлять частину судового розгляду [4]. Особливий статус дитини також слід враховувати в інших процесуальних процедурах. Особа до 18 років повинна лікуватися, пройти відповідне психологічне обстеження чи відповідний курс лікування відповідно до її віку та стану розвитку.

Перманентне зростання насильницьких злочинів проти малолітніх збільшує попит населення на послуги поліції, Служби прокуратури Королівства (CPS), департаментів дитячих служб місцевих органів влади, кримінальних і сімейних судів та спеціалізовані послуги громадського сектору для потерпілих (різноманітні громадські організації) [3]. Як наголошують англійські дослідники, провадження поліції та служб у справах дітей про насильницьку поведінку над дітьми є зміною життя для жертви. Коли провадження тривають довго, це спричиняє ризик посилення травми (насамперед у психологічному аспекті) дітей та їх сімей.

Зважаючи на цей фактор, Уповноважений 3 питань дитинства Великої Британії розглянув тривалість процесу кримінального судочинства. Для цього було використано дані Міністерства внутрішніх справ і національні дані з КПС для ви- вчення термінів, пов'язаних із випадками насильницьких злочинів проти дітей в Англії у період $2012 / 2013$ та $2015 / 2016$ років з точки зору початку та кінцевої роботи в суді.

Як показали результати дослідження, процес розслідування випадків насильницьких злочинів щодо дітей значно перевищує строк по таких злочинах щодо повнолітніх осіб. У 2015/2016 роках середня тривалість проваджень по насильницьких злочинах проти малолітніх становила 248 днів. Середня тривалість проваджень по насильницьких злочинах проти повнолітніх складала 147 днів, що на 101 день менше, ніж середнє значення для таких злочинів щодо малолітніх [3, с. 3]. Провадження, пов'язані з насильством над дітьми, тривають довше, ніж всі інші види злочинів, тому поліція та інші правоохоронні органи повинні вивчати способи більш ефективного функціонування, щоб мінімізувати затримки та збільшити швидкість прийняття рішень.

Уповноважений 3 питань дитинства запропонував реалізацію трьох заходів щодо підвищення якості та швидкості прийняття рішень при кримінальних розслідуваннях насильницьких злочинів проти малолітніх: ліцензування практики фахівців, які працюють у справах насильницьких злочинів проти малолітніх, для покращення процесу прийняття рішень при проведенні розслідувань; впровадження у поліцейські групи, які займаються розслідуваннями насильницьких злочинів проти малолітніх, спеціалістів, які будуть співпрацювати з поліцією; створення та розгортання «дитячих будинків», зручних для дітей місць, де жертви насильницьких злочинів проти малолітніх беруть участь у поліцейських інтерв'ю, а також отримують терапевтичну підтримку.

Попередні результати Уповноваженого з питань дитинства виявили поширеність і високу латентність насильницьких злочинів проти малолітніх в Англії, а також перешкоди та проблеми щодо виявлення дітей, які стали жертвами насильства. Вирішення таких бар'єрів і проблем може покращити ідентифікацію жертв насильницьких злочинів. Проте більша ідентифікація жертв призведе до збільшення попиту на ресурси між установами, існує й ризик того, що розгляд справ затягнеться.

3 огляду на соціально негативний вплив насильницьких злочинів проти малолітніх на жертв і зростаючий попит на відповідні охоронні послуги дуже важливо регулярно повідомляти про своєчасність процесу розслідування та судочинства, щоб забезпечити перевірку результативності. Зокрема, дані про результати розслідування та своєчасність судового провадження мають бути розподілені на опубліковані дані щодо потерпілих дітей і потерпілих дорослих, щоб забезпечити контроль за протидією насильницьких злочинів проти малолітніх. 
Не можна оминути увагою позитивний досвід у протидії насильницьких злочинів проти малолітніх в Сполучених Штатах Америки. За даними Федерального бюро розслідувань, у Сполучених Штатах Америки щороку тисячі дітей стають жертвами насильницьких злочинів, таких як сексуальне насильство та викрадення. Федеральне бюро розслідувань є головною інституцією Міністерства юстиції Сполучених Штатів Америки, відповідальною за розслідування злочинів проти дітей. Міністерство юстиції визначило захист дітей пріоритетом, як це відображено у Стратегічному плані, який включає запобігання, припинення та розслідування злочинів проти дітей та описує свої стратегії для досягнення цієї мети [5].

Пріоритетами в розслідуванні насильницьких злочинів проти дітей для ФБР є викрадення дітей, включаючи викрадення батьками та з батьками; сексуальна експлуатація дітей - організації, які займаються торгівлею дітьми; інтернет-мережі та підприємства, які займаються виробництвом, торгівлею, розповсюдженням та/або продажем дитячої порнографії; дитячий секс-туризм (міжнародні подорожі з сексуальної діяльності стосовно дітей); виробництво дитячої порнографії, в тому числі і примус / заманювання неповнолітнього; торгівля дитячою порнографією та розповсюдження дитячої порнографії; володіння дитячою порнографією.

Під час розслідувань насильницьких злочинів проти дітей докази та інформація про злочин збираються в основному з трьох джерел: жертви; підозрюваний; місце злочину (включаючи інших свідків). Співробітники повинні ретельно вивчати всі три джерела та будь-які інші доступні джерела доказів чи інформації. Однак розслідування можуть бути успішними, навіть якщо докази недоступні з усіх трьох джерел. У відповідь на скарги на насилля необхідно докладати максимум зусиль, щоб звільнити потерпілого від почуття сорому та/або самогубства. Щоб жертви могли надавати найочевиднішу та найбільш повну інформацію про злочин, необхідно докласти зусиль для забезпечення того, щоб всі заходи проводилися професійно та гідно [6].

Розслідування насильницьких злочинів щодо дітей проводяться відділеннями ФБР, зокрема відділеннями спеціальних підрозділів по боротьбі з експлуатацією дітей (CETF), які поєднують ресурси ФБР з іншими федеральними, штатними та місцевими правоохоронними органами. Для всіх правоохоронців, залучених до цих розслідувань, включаючи федеральні, державні, місцеві та іноземні правоохоронні органи, проводяться спеціальні тренінги. За американським законодавством ордер на арешт злочинця може бути виданий на одного з батьків, який вивіз неповнолітнього віком до 16 років за межі США без дозволу другого з батьків [7].
До державних правових основ міжнародного співробітництва насамперед належить Конституція України, яка містить положення, що визначає міжнародні договори України частиною її правової системи (ст. 9) та зазначає, що зовнішньополітична діяльність України спрямована на забезпечення ії̈ національних інтересів і безпеки шляхом підтримання мирного і взаємовигідного співробітництва з членами міжнародного співтовариства за загальновизнаними принципами і нормами міжнародного права (ст. 18).

З метою вивчення стану й тенденцій злочинності в окремих регіонах світу кожні п'ять років, починаючи з 1955 року, здійснюються науково-практичні заходи, які організовуються ООН і мають назву «Конгреси $\mathrm{OOH}$ із запобігання злочинності і кримінального правосуддя» [8, с. 9-27]. Результати проведення 13-го Конгресу відображені в Дохійській декларації, в якій зазначені основні проблеми у сфері запобігання злочинності й кримінального правосуддя. Автор розглядає вказані питання докладніше.

Так, протягом 2003-2017 років у світі відбулося незначне зростання насильницької злочинності. Кримінологічно значущими є відомості про зв'язок злочинності й рівня доходів в окремих групах країн. Так, у групі країн з високим рівнем доходів (США, країни-члени ЄС) відбулося зниження за всіма видами майнових і насильницьких злочинів. Щодо країн із низьким рівнем доходів (держави Африки і Латинської Америки), то в них навпаки спостерігається збільшення рівня основних злочинів загальнокримінальної спрямованості, за винятком злочинів у сфері незаконного обігу наркотиків [9]. Зазначені показники вказують на те, що у 2003-2017 роках соціально-економічні детермінанти значно вплинули на характер і тенденції злочинності в багатьох країнах світу.

На 13-му Конгресі експертами ООН було наведено додаткові аргументи щодо зв'язку підвищеного рівня вбивств та інших насильницьких злочинів, в тому числі вчинених щодо дітей, із соціально-економічним розвитком в різних державах світу [10]. Фахівці ООН вказують, що на сучасному етапі розвитку суспільства однією з найпоширеніших форм транснаціональної організованої злочинності останнім часом є сексуальна експлуатація дітей. До корінних причин перелічених форм злочинності прийнято відносити глобалізацію, соціальну нерівність, розбалансованість правоохоронної системи, розвиток сучасних інформаційних технологій. Вказані криміногенні чинники сприяють перетворенню колись локальних злочинів на глобальні негативні явища соціальної дійсності.

Поширенню сучасних викликів світовій спільноті у вигляді різних злочинів сприяє можливість отримання незаконних надприбутків. Серед основних напрямів запобігання транснаціональній 
організованій злочинності виділяють розробку національного законодавства в сфері запобігання вказаним злочинам, посилення міжнародного співробітництва та удосконалення діяльності органів кримінальної юстиції [11].

Аналіз матеріалів усіх 13-ти конгресів $\mathrm{OOH}$ із запобігання злочинності і кримінального правосуддя дає підстави стверджувати, що світова спільнота приділяе все більше уваги залучен-

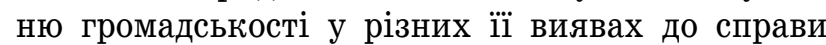
протидії злочинності. Цей напрям діяльності на 7-му Конгресі $\mathrm{OOH}$ із запобігання злочинності i поводженню із правопорушниками (м. Мілан, 1985 року) виділений як окрема стратегія запобігання злочинності. Прогресивна міжнародна практика громадського впливу на злочинність та активізація її діяльності в цій сфері свідчить, що найчастіше громадськість використовується з метою вивчення стану місцевої злочинності (Колумбія, ПАР); запобігання рецидивній злочинності (Сінгапур, Бразилія, Уганда, Кенія); охорони громадського порядку (США, Велика Британія, Перу, Бразилія); надання безоплатної юридичної допомоги (Ботсвана, Зімбабве, Лесото, Нігерія, Кенія, Малаві, Уганда, Сьєрра-Леоне); фінансового заохочення громадськості за її внесок у справу запобігання злочинності (Австралія, Канада); використаннязасобівкомунікаціїузапобіганнізлочинності (США, Велика Британія, Австралія) тощо [12].

Якщо ж вести мову про напрями залучення громадськості при запобіганні насильницькій злочинності щодо дітей, то сюди можна віднести сумісне проведення поліцією і громадянами інформаційно-пропагандистських кампаній із профілактики насильницьких злочинів щодо дітей; читання поліцейськими лекцій у школах та вузах (програма "Escola Sugura” («Безпечні школи») в Португаліі); підвищення ролі науково-дослідних установ у вивченні тенденцій і характеру місцевої насильницької злочинності щодо малолітніх з метою удосконалення роботи поліції й розширення ролі громадськості у запобіганні злочинності (Уругвай) [12].

Можна виділити типові проблеми щодо співпраці з громадськістю в світі у запобіганні злочинності щодо дітей. Насамперед це обмеженість знань про порядок і умови застосування стратегії громадського впливу; відсутність співпраці між поліцією та громадянами; відсутність політичної рішучості з боку влади; відсутність контролю за особами, звільненими $з$ мість позбавлення волі та інші.

Узагальнення сучасних тенденцій і стратегій протидії насильницькій злочинності щодо малолітніх в різних країнах світу дає підстави для отримання таких висновків: сучасні світові насильницькі злочини щодо дітей характеризуються відносною сталістю кількісних показників за більшістю майнових і насильницьких злочинів; найпоширенішими прибутковими видами транснаціональної організованої злочинності відносно малолітніх дітей є злочинність у сфері торгівлі дітьми; сексуальної експлуатації; використання в порнобізнесі; вилучення органів, проведення дослідів над дітьми; успішне запобігання більшості злочинам не можливе без широкої участі громадськості; стратегія громадського впливу на злочинність полягає у залученні окремих громадян, громадських організацій правоохоронної спрямованості до охорони правопорядку, участі в програмах профілактики насильницької злочинності щодо малолітніх дітей, надання інформації про вчинені злочини 3 обов'язковим матеріальним заохоченням цих напрямів роботи з боку держави і приватного бізнесу.

Одним із важливих аспектів ефективного розслідування насильницьких злочинів у державах Європи та Сполучених Штатах Америки є значна увага початковому етапу розслідування. При цьому основним пріоритетом є забезпечення психологічного здоров'я дитини. Тому час проведення, порядок проведення слідчих дій багато в чому визначається саме цим фактором.

До прогресивних практик у сфері запобігання торгівлі дітьми і дорослими людьми в різних країнах належить створення «чорних» списків трудових агенцій, незаконних вербувальників, щодо яких відкриті кримінальні провадження за посередництво у торгівлі живим товаром (Філіппіни); недопущення перетворення жертв торгівлі людьми, які примусово працюють, на нелегальних мігрантів; надання жертвам торгівлі людьми належної соціальної й психологічної допомоги 3 метою їх активної участі в розслідуванні злочинів і притягнення винних осіб до відповідальності; поширення практики компенсації жертвам торгівлі людьми за їх страждання.

Висновки. Варто зазначити, що сучасний передовий міжнародний досвід запобігання насильницькій злочинності щодо дітей має враховуватися державними органами України при розробці й практичній реалізації стратегій протидії такій злочинності в нашій державі. Аналіз зарубіжного досвіду в цій сфері вказує як на проблеми, з якими стикаються зарубіжні правоохоронці, так і на окремі заходи, які можна запровадити в національну правову систему.

1. Crimes against children. URL: https://www.interpol.int/en/...and.../Crimes-againstchildren.

2. Дакал А. Зарубіжний досвід формування та реалізації державної політики щодо захисту прав дітей: роль інституту омбудсмана у справах дітей. Вісник Національної академії державного управління. 2012. Вип. 4. С. 211-219.

3. Tuominen M., Ellonen N. Criminal investigation in violent and sex crimes against children. URL: https://www.ncbi.nlm.nih.gov/pubmed/26237878. 
4. Investigating Child Sexual Abuse. The Length of Criminal Investigations. April, 2017. 15 p.

5. The Federal Bureau of Investigation's Efforts to Combat Crimes Against Children. URL: https://oig.justice.gov/reports/FBI/a0908/final.pdf.

6. Pocket Guide for Police Response to Sexual Assault. URL: https://ovc.ncjrs.gov/sartkit/tools/ lawenforcement/Pocket $\%$ 20Guide $\% 20$ for $\% 20$ Police $\%$ 20Response $\%$ 20to $\%$ 20Sexual $\%$ 20Assault.pdf.pdf.

7. Violent Crimes Against Children / Online Predators. URL: https://www.fbi.gov/investigate/violent-crime/cac.

8. Конгрессы ООН по предупреждению преступности и уголовному правосудию : сб. материалов: в 3 кн. Кн. 1 / Нац. акад. прав. наук Украины; НИИ изучения проблем преступности им. акад. В.В. Сташиса; кол. сост.: В.В. Голина, М.Г. Колодяжный; под ред. В.В. Голины. Киев : Ред. журн. «Право Украины»; Харьков : Право, 2013. 188 с.

9. State of crime and criminal justice worldwide: Report of the Secretary-General / Thirteenth United Nations Congress on Crime Prevention and Criminal Justice (Doha, Qatar, 12-19 April 2015), 39 p.

10. Accounting for Security and Justice in the Post2015 Development Agenda / UNODC. Vienna, 2013.149p.

11. Comprehensive and balanced approaches to prevent and adequately respond to new and emerging forms of transnational crime: Working paper prepared by the Secretariat / Thirteenth United Nations Congress on Crime Prevention and Criminal Justice (Doha, Qatar, 12-19 April 2015), $20 \mathrm{p}$.

12. National approaches to public participation in strengthening crime prevention and criminal justice: Working paper. Thirteenth United Nations Congress on Crime Prevention and Criminal Justice (Doha, Qatar, 12-19 April 2015), 18 p.

\section{Анотація}

Корнієнко М. В. Деякі аспекти використання міжнародного досвіду під час розслідування насильницьких злочинів щодо дітей. - Стаття.

В Україні відбуваються складні соціально-економічні перетворення, які безпосередньо впливають на збільшення випадків потрапляння дитини у складні життєві обставини, вчинення жорстокого поводження щодо дитини, втягування дітей у кримінальні угруповання, залучення до жебрацтва та скоєння відносно дітей насильницьких злочинів, як ніколи діти потребують захисту та допомоги держави.

В державі реалізуються підходи, визначені міжнародним і вітчизняним законодавством стосовно захисту прав дітей, держава захищає інтереси дитини, удосконалює механізми контролю за дотриманням чинного законодавства в сфері охорони дитинства, розвиває та вдосконалює інституції соціально-правового захисту дітей. Однак цього замало, існує безліч прогалин у законодавстві, які потребують вирішення найближчим часом.

Інтерпол наголошує: «Злочини проти малолітніх останнім часом починають набувати міжнародного характеру. Винні особи можуть переїжджати з держави в державу, зокрема у країни, які розвиваються, зважаючи на меншу суворість покарання». Сучасне правове дослідженн умовах глобалізації та євроінтеграції не може не враховувати порівняльно-правового аспекту. Становлення і розвиток юридичної компаративіс- тики є важливим фактором удосконалення правозастосовної діяльності органів державної влади, в тому числі і у сфері діяльності правоохоронних органів, зокрема протидії насильницьким злочинам проти дітей.

Для більш ефективного розслідування насильницьких злочинів щодо дітей і використання позитивного міжнародного досвіду потрібно узагальнити деякі сучасні тенденції і стратегії протидії насильницькій злочинності щодо малолітніх, розглянути типові проблеми у запобіганні злочинності, з якими стикаються в різних державах. Запозичення досвіду розвинутих країн, насамперед держав Європи, має певні проблемні аспекти, пов'язані з різним законодавчим регулюванням відповідних суспільних відносин.

Ключові слова: дитина, захист дитини, нормативний акт, міжнародне право, конвенція, юридична відповідальність, законодавство України, міжнародні стандарти, нормативна база.

\section{Summary}

Korniienko $M . V$. Some aspects of using international experience to investigate violent crimes against children. - Article.

In Ukraine today there are difficult socio-economic transformations that directly influence on the increase ofcases of hit of child in difficult vital circumstances, feasance oflegal cruelty in relation to a child, involvement of children incriminal organizations, bringing in to begging and feasance inrelation to the children of crimes of violence, as no time to putneed defence and help of the state.

In the state approaches will be realized certain aninternational and home legislation in relation to the protectionof rights forchildren, the state protects interests of child, perfects a control mechanism after the observance of currentlegislation in the field of the guard of childhood, develops andperfects institutes sociallegal defence of children and otherslike that, but it not enough, exist enormous amount of blanksin a legislation, that need a decision the nearest time.

As Interpol marks Crimes against very young in the last timesbegin to acquire international character. Winy persons canmove from the state in the state, in particular, in countries thatdevelop, having regard to the less strictness of punishment. Modern legal research, in the conditions of globalization and eurointegration, takes into account a comparatively-legalaspect. Becoming and development of legal is the important factor of improvement of law enforcement activity of public authorities, including in the field of activity of law enforcement authorities, in particularto counteraction to the crimes of violence against children.

For more effective investigation of crimes of violence inrelation to children and use of positive international experience we need to generalize some modern tendenciesand strategies of counteraction to violent criminality in relationto very young, will consider typical problems in prevention ofcriminality, with that clash in the different states, at the same time borrowing of experience of the developed countries, in the first turn the states of Europe, has the problem aspectsrelated to the different legislative adjusting correspondingpublic relation are certain.

Key words: child, child protection, normative act, international law, convention, legal liability, legislation of Ukraine, international standards, normative base. 